\title{
Participative Management Style: A Tool to Enhance Quality Education
}

\author{
Dr. Mubasher Nadeem \\ Director Division of Arts \& Social Sciences University of Education, Lower Mall Campus Lahore
}

\begin{abstract}
Different management styles are in vogue in the management world and are practised by educational managers to enhance individual and collective efficiency of employees. The study surveys the efficacy of participative management style that to what extent it is effective in the modern educational requirements. The study was conducted on one hundred elementary and secondary schools' educational managers of public and private sectors. The data were collected through a questionnaire regarding the type of management educational managers/administrators practise in their organizations. The results reflect that private sector school managers prefer participative management style to others for effective output and achieve various academic and administrative benefits as compared to public sector educational managers who appear to be reluctant to practise participative management style and their practised approach manifests that they like to remain dominant in administrative affairs. But through participative management style millions of public sector students could be given harmonious educational environment which is friendly, accommodating and helpful in their academic career and could bring back the golden days of public sector schools. Hence, the study suggests that public sector school managers should be offered management courses frequently so that by implementing participative management style quality education could be ensured.
\end{abstract}

Key Words: Management, educational managers, collective efficacy, participative management,

\section{Introduction}

Flippo (1984) states that at one time in our history, "liking people" appeared to be sufficient for choosing to work in the field known as personnel management. Preferring to work with humans rather than objects is still important, but it is grossly insufficient in these modern times. Personnel management is one of our most complex and challenging fields of endeavor. A manager's style is determined by the situation, the needs and personalities of his or her employees, and by the culture of the organization. Organizational restructuring and the accompanying cultural change has caused management styles to come in and go out of fashion.

There is increasing emphasis on improving quality and demonstrating accountability in the field of adult education. In the past, much of this emphasis focused on the assessment of instructor quality and learner outcomes. However, performance by instructors and learners depends, in part, on the resources available, the environment in which the program operates, and the level of support received from program administrators. Therefore, quality adult education programs need administrators of the highest caliber (Sherman et al., 2002).

There has been a move away from an authoritarian style of management in which control is a key concept, to one that favors teamwork and empowerment. Managerial styles that focus on managers as technical experts who direct, coordinate and control the work of others have been replaced by those that focus on managers as coaches, counselors, facilitators, and team leaders (management styles, II 1).

There are different management styles, i.e., laissez-faire, participative and autocratic, etc, available and are utilized by educational managers both in office as well as in the field work to achieve the set targets aimed to enhance personal and collective efficiency of the employees on one hand and the students on the other in the schools. In the prevalent educational scenario appropriate management style could determine the possible improvement of the concerned personnel and the organization. The study surveys the type of management style practised by the school managers in accordance with growing demands in the field of education in the present educational set up.

\section{Research question}

The study aims to find out what management style the educational managers (of elementary/secondary schools) in the private and public sectors practise for the achievement of academic and managerial goals.

\section{Objectives of study}

The main objectives of this study are to:

Find out the management styles of (Male/Female) Head Teachers of public and private schools at Elementary/Secondary level. 
Understand the participation level of teachers/employees in decision making in the public and private Elementary/Secondary schools.

Evaluate the management expertise of Elementary/Secondary schools' managers.

\section{Methodology and Procedure}

The study has been conducted on one hundred educational managers, i.e., head teachers of elementary/secondary (male/female) schools in Lahore district both of public and private sectors (urban and non-urban) and the data were collected through a questionnaire (Appendix: A).

\section{Review of Literature}

An extensive body of research has shown that participative management - defined as joint decision making or at least shared influence in decision making by a superior and his or her employees (Koopman and Wierdsma, 1998) - offers a variety of potential benefits to the overall school organization and to its employees (Day et al., 2005; Gebert et al., 2003). Nevertheless, studies (Sato et al., 2002) have also indicated that teacher involvement in the decision-making process can generate job-related stress and role ambiguity and can create tension and conflict among teachers, principals, and administrators. Participative management challenges traditional practices and encourages autonomy, openness to new suggestions or ideas, and novel objectives (West, 2002). A participative management environment involves an increase in social and mental demands, such as job meaningfulness, responsibility for others and collaboration (Stevens \& Ash, 2001).

Weihrich et al., (2008) says that one of the most important human activities is managing. Ever since people began forming groups to accomplish aims they could not achieve as individuals, managing has been essential to ensure the coordination of individual efforts. As society has come to rely increasingly on group effort, and as many organized groups have become large, the task of managers has been rising in importance. Participative management gives employees more responsibility for organizational performance and for making planning and organizing decisions, thus inherently signaling that the organization recognizes the employee can make important contributions to it (Luthans, 1995; Stevens \& Ash, 2001). Previous studies (Penley and Tomaka, 2002; Vollrath, 2001) have indicated that highly conscientious individuals perceive themselves as able to meet situational demands, tend more readily to accept responsibility for problems that arise and persevere even when facing obstacles.

Working in a participative management environment tends to foster more interaction among team members and requires individuals who have robust social skills (Lawler, 1992). But researchers (Argyle \& Lu, 1990; Hills \& Argyle, 2001) have indicated that social interaction can be a major source of pleasure and happiness for highly extroverted individuals, which, in turn, generates positive moods and ultimately overall happiness (Tkach \& Lyubomirsky, 2006). Participative management has the potential to balance the involvement of managers and their subordinates in information-processing, decision-making, or problemsolving endeavors (Wagner, 1994).

A participative management environment helps teachers discover new opportunities and challenges and enables them to learn by acquiring, sharing, and combining knowledge (Edmondson, 1999). High levels of conscientiousness are characterized by a general tendency to be involved in work, entailing a greater likelihood of obtaining satisfying formal and informal work rewards (respect, sense of personal accomplishment) (Organ \& Lingl, 1995). Robbins \& Coulter (1996) opine that participative/democratic describes a leader who tends to involve subordinates in decision making, delegate authority, encourage participation in deciding work methods and goals, and use feedback as an opportunity for coaching. Participative management, in fact, promotes a sense of 'we feeling' among the employees and enable to own the decisions taken by the managers.

Participative (or participatory) management, otherwise known as employee involvement or participative decision making, encourages the involvement of stakeholders at all levels of an organization in the analysis of problems, development of strategies, and implementation of solutions. Mullins (2008) states that the democratic style is where the focus of power is more with the group as a whole and there is greater interaction with the group. The leadership functions are shared with members of the group and the manger is more part of a team. The group members have a greater say in decision making, determination of a policy, implementation of systems and procedures.

Employees are invited to share in the decision-making process of the firm by participating in activities such as setting goals, determining work schedules, and making suggestions. Other forms of participative management include increasing the responsibility of employees (job enrichment); forming self-managed teams, quality circles, or quality-of-work-life committees; and soliciting survey feedback. Participative management, however, involves more than allowing employees to take part in making decisions. It also involves management treating the ideas and suggestions of employees with consideration and respect. The most extensive form of participative management is direct employee ownership of a company (Participative Management, If 2). 
Weihrich et al (2008) say that democratic or participative leader consults with subordinates on proposed actions and decisions and encourages participation from them. This type of leader ranges from the person who does not take action without subordinates' concurrence to the one who makes decisions but consults with subordinates before doing so. Participative management practices are commonly perceived as offering a variety of potential benefits for the organization and for workers' mental health and job satisfaction (Aryee \& Chen, 2006; Kim, 2002). Nevertheless, such an environment, which is marked by shared decision making and a high level of interaction and cooperation among teachers and between teachers and principals (Blase \& Blase, 1994), may actually be harmful for some, as it generates additional pressure and perceived stress due to added challenges, responsibility and accountability.

Khaparde et al., (2004) research indicated that successful schools adopted participative management system in running day-to-day activities of the schools, gave people autonomy but also made them accountable for successful completion of the tasks, followed democratic methods of taking decisions, gave priority to the welfare of students, maintained supportive relationship with teachers, attempted to establish linkage with parents, set up higher and higher goals for themselves and the schools, adopted innovative pedagogical methods and evaluation devices, and recognized good work of the teachers. The results have implications for other schools where some of these devices can be tried out to improve their performance.

Participative management style may promote sort of micro leadership feeling that enhances individual role for the organization and the students. Since all the employees, working under a supervisor, cherish the idea to support the organization unconditionally as the supervisors, head teacher offer a leadership role to each one of them. Involvement in decision-making improves the understanding of the issues involved by those who must carry out the decisions. And that could be on the following assumptions:

$\checkmark \quad$ People are more committed to actions where they have involved in the relevant decision-making;

$\checkmark \quad$ People are less competitive and more collaborative when they are working on joint goals;

$\checkmark \quad$ When people make decisions together, the social commitment to one another is greater and thus increases their commitment to the decision; and

$\checkmark \quad$ Several people deciding together make better decisions than one person alone (Participative Leadership: Assumptions II 1).

\section{Findings and Discussion}

Results of the study reflect that a majority of educational managers in the private sector schools practise participative management style as they feel participative management style not only creates conducive educational environment for the managers to get the job done but also facilitates the employees to work for the betterment of the organization. Whereas public sector head teachers, due to certain administrative constraints, do not apply participative management style in the organization as the results show.

The study further manifets that public sector schools' heads do not prefer to use participative management style and results reflect that there is less participation of the employees in the school management or decision making process. As the results show that $60 \%$ of the public sector managers are prone to authoritative style of management which enables us to understand that there is either a communication gap between the manager and the employees or some authoritarian conduct which does not allow them to permit employees to participate in the school affairs and decision making

Table 1: Management style of Public Sector School Head teachers (N=50)

\begin{tabular}{|c|c|c|c|}
\hline Sr. No. & Leadership Styles & $\begin{array}{c}\text { Public Sector School } \\
\text { Managers }\end{array}$ & \% age \\
\hline 01 & Autocratic Style & $\mathbf{3 0}$ & $\mathbf{6 0}$ \\
\hline 02 & Participative Style & $\mathbf{0 8}$ & $\mathbf{1 6}$ \\
\hline 03 & Delegative Style & $\mathbf{1 2}$ & $\mathbf{2 4}$ \\
\hline
\end{tabular}




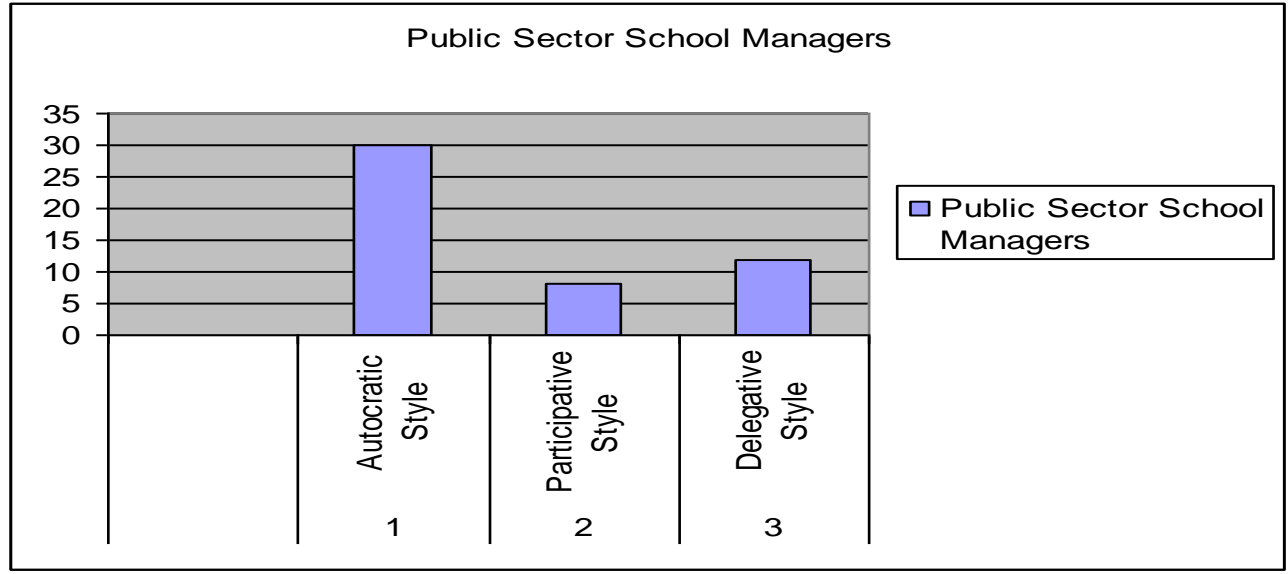

Whereas on the other hand we find that only $10 \%$ private sector school managers prefer to use autocratic management style and a majority $70 \%$ practises participative management style and managers allow employees to share responsibilities and contribute their input in decision making which, eventually, benefits the recipient of education-children.

Table 2: Management style of Private Sector School Head teachers ( $\mathrm{N}=50)$

\begin{tabular}{|c|c|c|c|}
\hline Sr. No. & Leadership Styles & $\begin{array}{c}\text { Public Sector School } \\
\text { Managers }\end{array}$ & \% age \\
\hline 01 & Autocratic Style & $\mathbf{0 5}$ & $\mathbf{1 0}$ \\
\hline 02 & Participative Style & $\mathbf{3 5}$ & $\mathbf{7 0}$ \\
\hline 03 & Delegative Style & $\mathbf{1 0}$ & $\mathbf{2 0}$ \\
\hline
\end{tabular}

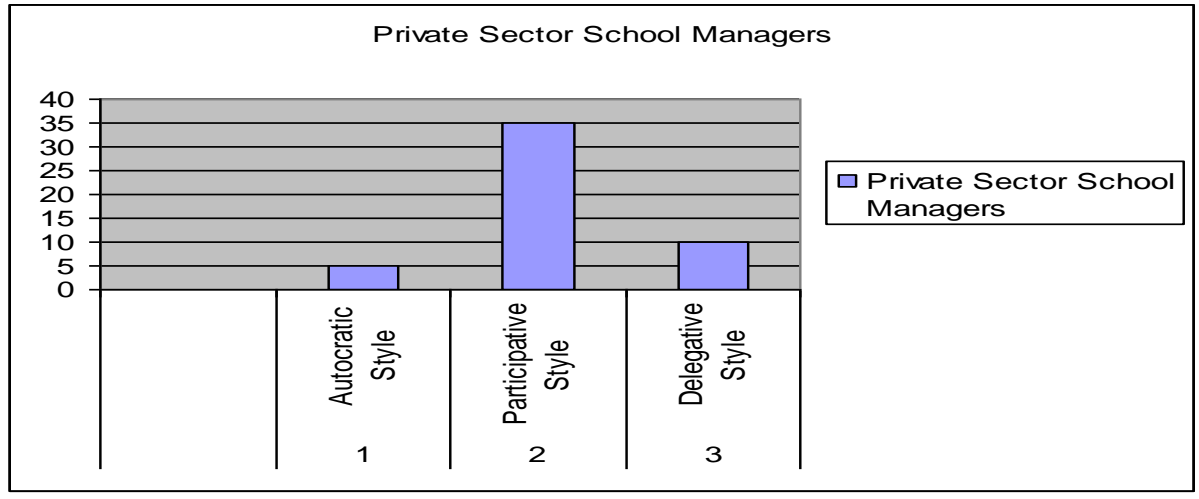

The results also present the actual state of affairs in the public sector schools where millions of children go to seek knowledge to use in the coming years but in light of the results it is difficult to say whether they (students) will be able to learn the required skills necessary to utilize in the globalized world as there seems less sense of belonging imparted by the employees because the schools managers rarely allow employees to participate fully in managerial work and have to shoulder what is said or expected without their own willingness. But things are different in the private sector so far as participation of the employees in schools or management is concerned. Matters are discussed with them and their input is given weightage in decision making. Eventually employees generate confidence building attitude among them which is also transferred to the students/learners.

Hence, people prefer to send their children to private schools which, on one hand, question the efforts of the government for uplifting the image of public schools and the standard of education at these schools on the other. For quality education it is imperative for school managers to practise such management style that may contribute to employees/teachers and students' life as well as in the development of the country because it is the quality education that determines the fate of a nation. 


\section{Conclusion and Recommendations}

The study concludes that there is a lack of participative management style in the public sector schools as compared with the private schools where the school managers try to generate 'We Feeling' among the employees and gain good results. In light of the findings of the study it is pertinent to say that for better organizational results and benefits it is appropriate to practise participative management style in the public sector elementary/secondary schools as this level shapes the future of coming generations as is practised by the educational managers of the private sector schools' heads. For this there must be an effort to:

- $\quad$ train the head teachers and administrators to encourage participative management style in the schools;

- $\quad$ ask policy makers to hold workshops and seminars for schools' heads on the importance of participative management;

- monitor the public sector schools' heads to determine whether the head teachers practise participative management or not;

- $\quad$ ask school public sector schools' heads to hold workshops in their schools on the benefits of participative management;

- $\quad$ ensure community involvement in the school affairs through school management councils; and

- $\quad$ ask the school managers to encourage participation of the employees in the school's affairs and let the employees play their role in decision making.

\section{References}

[1] Argyle, M., \& Lu, L. (1990), "Happiness and social skills", Personality and Individual Differences, Vol. 11, pp. 1255-61.

[2] Aryee, S., \& Chen, Z.X. (2006), "Leader-member exchange in a Chinese context: antecedents, the mediating role of psychological empowerment and outcomes", Journal of Business Research, Vol. 59, pp. 793-801.

[3] Blase, J., \& Blase, J.R. (1994), Empowering Teachers: What Successful Principals Do, Corwin, Thousand Oaks, CA.

[4] Day, C., Elliot, B., \& Kington, A. (2005), "Reform, standards and teacher identity: challenges of sustaining commitment", Teaching and Teacher Education, Vol. 21, pp. 563-7.

[5] Flippo, B.E. (1984). Personnel Management. Singapore: McGraw-Hill.

[6] Gebert, D., Boerner, S., \& Lanwehr, R. (2003), "The risks of autonomy: empirical evidence for the necessity of a balance management in promoting organizational innovativeness", Creativity and Innovation Management, Vol. 12, pp. 41-9.

[7] Hills, P., \& Argyle, M. (2001), "Emotional stability as a major dimension of happiness", Personality and Individual Differences, Vol. 31, pp. 1357-64.

[8] Khaparde,M. S., Srivastava,K. A , \& Meganathan, R. (2004) Successful School Management in India: Case Studies of Navodaya Vidyalayas, Educational Research for Policy and Practice, Volume 3, Number 3 / January, 2004, p. 1

[9] Kim, S. (2002), "Participative management and job satisfaction: lessons for management leadership", Public Administration Review, Vol. 62, pp. 231-41.

[10] Koopman, P.L., \& Wierdsma, A.F.M. (1998), "Participative management", in Drenth, P.J.D., Thierry, H. and De Wolff, C.J. (Eds), Handbook of Work and Organizational Psychology, Volume 3: Personnel Psychology, Psychology Press, Hove, pp. $297-324$.

[11] Lawler, E.E. III (1992), The Ultimate Advantage: Creating the High-involvement Organization, Jossey-Bass, San Francisco, CA

[12] Luthans, F. (1995), Organizational Behavior, McGraw-Hill, New York, NY.

[13] Management Styles. (Retrieved March 20, 2012) from http://www.referenceforbusiness.com/management/Log-Mar/Management-Styles.html

[14] Mullins, J.L. (2008). Management and Organizational Behaviour. $7^{\text {th }}$ edn. United Kingdom: Pearson Education LTD.

[15] Organ, D.W., \& Lingl, A. (1995), "Personality, satisfaction, and organizational citizenship behavior", Journal of Social Psychology, Vol. 135, pp. 339-50.

[16] Participative Leadership: Assumptions. (Retrieved April 25, 2012) from http://changingminds.org/disciplines/leadership/styles/participative leadership.htm (Challenging Minds)

[17] Participative Management. (Retrieved March 17, 2012) from http://www.enotes.com/management-encyclopedia/participativemanagement

[18] Penley, J.A., \& Tomaka, J. (2002), “Associations among the Big Five, emotional responses and coping with acute stress", Personality and Individual Differences, Vol. 32, pp. 1215-28.

[19] Robbins, P. Stephen., \& Coulter, M. (1996). Management. $5^{\text {th }}$ edn. New Jersey: Prentice -Hall Inc.

[20] Sato, M., Hyler, M.E., \& Monte-Sano, C. (2002), "The National Board Certification process and its impact on teacher leadership", paper presented at the Annual Meeting of the American Educational Research Association, New Orleans, LA.

[21] Stevens, C.D., \& Ash, R.A. (2001), "Selecting employees for fit: personality and preferred managerial style”, Journal of Managerial Issues, Vol. 13, pp. 500-17.

[22] Tkach, C., \& Lyubomirsky, S. (2006), "How do people pursue happiness? Relating personality, happiness-increasing strategies, and wellbeing", Journal of Happiness Studies, Vol. 7, pp. 183-225.

[23] Vollrath, M. (2001), "Personality and stress", Scandinavian Journal of Psychology, Vol. 42, pp. 335-47.

[24] Wagner, J.A. III (1994), "Participation's effect on performance and satisfaction: a reconsideration of research evidence", Academy of Management Review, Vol. 19, pp. 312-30.

[25] Weihrich, H., Cannice, V. M., \& Koontz, H (2008). Management: A Global and Entrepreneurial Perspective. $12^{\text {th }}$ edn, New Delhi: McGraw-Hill.

[26] West, M.A. (2002), "Sparkling fountains or stagnant ponds? An integrative model of creativity and innovation implementation in work groups", Applied Psychology: An International Review, Vol. 51, pp. 355-424. 


\begin{tabular}{|c|c|c|c|c|c|c|}
\hline \multicolumn{7}{|c|}{$\begin{array}{l}\text { Appendix: A } \\
\text { Questionnaire } \\
\end{array}$} \\
\hline $\begin{array}{l}\text { Sr. } \\
\text { No }\end{array}$ & Statement & $\begin{array}{l}\text { Almost } \\
\text { Always } \\
\text { True }\end{array}$ & $\begin{array}{l}\text { Frequently } \\
\text { True }\end{array}$ & $\begin{array}{l}\text { Occasionally } \\
\text { True }\end{array}$ & $\begin{array}{l}\text { Seldom } \\
\text { True }\end{array}$ & $\begin{array}{l}\text { Almost } \\
\text { Never } \\
\text { True }\end{array}$ \\
\hline 1. & $\begin{array}{l}\text { I always retain the final decision making } \\
\text { authority within my department or team. }\end{array}$ & & & & & \\
\hline 2. & $\begin{array}{l}\text { I always try to include one or more } \\
\text { employees in determining what to do and } \\
\text { how to do it. However, I maintain the final } \\
\text { decision making authority. }\end{array}$ & & & & & \\
\hline 3. & $\begin{array}{l}\text { I and my employees always vote whenever a } \\
\text { major decision has to be made. }\end{array}$ & & & & & \\
\hline 4. & $\begin{array}{l}\text { I do not consider suggestions made by my } \\
\text { employees as I do not have the time for } \\
\text { them. }\end{array}$ & & & & & \\
\hline 5. & $\begin{array}{l}\text { I ask for employee ideas and input on } \\
\text { upcoming plans and projects. }\end{array}$ & & & & & \\
\hline 6. & $\begin{array}{l}\text { For a major decision to pass in my } \\
\text { department, it must have the approval of } \\
\text { each individual or the majority. }\end{array}$ & & & & & \\
\hline 7. & $\begin{array}{l}\text { I tell my employees what has to be done and } \\
\text { how to do it. }\end{array}$ & & & & & \\
\hline 8. & $\begin{array}{l}\text { When things go wrong and I need to create a } \\
\text { strategy to keep a project or process running } \\
\text { on schedule, I call a meeting to get my } \\
\text { employee's advice. }\end{array}$ & & & & & \\
\hline 9. & $\begin{array}{l}\text { To get information out, I send it by email, } \\
\text { memos, or voice mail; very rarely is a } \\
\text { meeting called. My employees are then } \\
\text { expected to act upon the information. }\end{array}$ & & & & & \\
\hline 10. & $\begin{array}{l}\text { When someone makes a mistake, I tell them } \\
\text { not to ever do that again and make a note of } \\
\text { it. }\end{array}$ & & & & & \\
\hline 11. & $\begin{array}{l}\text { I want to create an environment where the } \\
\text { employees take ownership of the project. I } \\
\text { allow them to participate in the decision } \\
\text { making process. }\end{array}$ & & & & & \\
\hline 12. & $\begin{array}{l}\text { I allow my employees to determine what } \\
\text { needs to be done and how to do it. }\end{array}$ & & & & & \\
\hline 13. & $\begin{array}{l}\text { New hires are not allowed to make any } \\
\text { decisions unless it is approved by me first. }\end{array}$ & & & & & \\
\hline 14. & $\begin{array}{l}\text { I ask employees for their vision of where } \\
\text { they see their jobs going and then use their } \\
\text { vision where appropriate. }\end{array}$ & & & & & \\
\hline 15. & $\begin{array}{l}\text { My workers know more about their jobs than } \\
\text { me, so I allow them to carry out the decisions } \\
\text { to do their job. }\end{array}$ & & & & & \\
\hline 16. & $\begin{array}{l}\text { When something goes wrong, I tell my } \\
\text { employees that a procedure is not working }\end{array}$ & & & & & \\
\hline
\end{tabular}




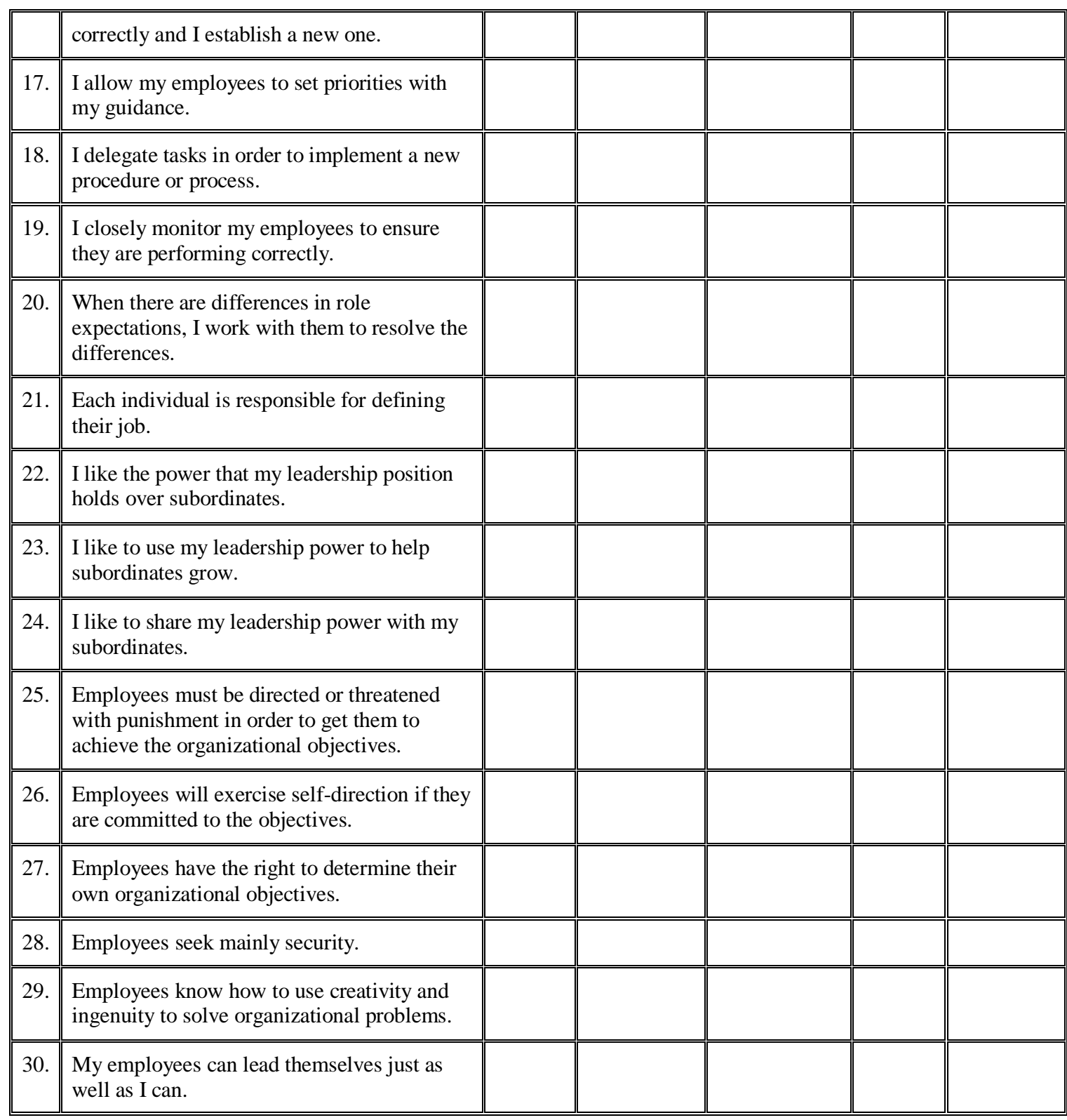

